\title{
МЕДИКО-СОЦІАЛЬНІ АСПЕКТИ КАРДІОЛОГІЧНОЇ ПАТОЛОГІЇ СЕРЕД ПРАЦІВНИКІВ ТА УЧНІВ СПЕЦІАЛІЗОВАНОГО ЗАКЛАДУ СЕРЕДНЬОЇ TEXHIЧHOÏ ОСВITИ
}

\author{
І. В. Радіонова ${ }^{1}$, Л. В. Левицька ${ }^{2}$ \\ ${ }^{1}$ Криворізький професійний гірничо-металургійний ліцей \\ ${ }^{2}$ ДвНЗ «Тернопільський державний медичний університет \\ імені І. Я. Горбачевського МОЗ Украӥни"
}

У статті обгрунтовано доцільність вивчення медико-соціальних аспектів серцево-судинного здоров’я серед різних популяцій населення, оцінки кардіоваскулярних ризиків та модифікації стилю життя, а також чітких навичок профілактичної роботи медичної сестри у цьому аспекті.

\section{MEDICAL-SOCIAL ASPECTS OF CARDIOLOGICAL PATHOLOGY IN EDUCATION, ACADEMIC AND RESEARCH WORKERS AND STUDENTS OF TECHNICAL COLLEGE}

\author{
I. V. Radionova ${ }^{1}$, L. V. Levytska ${ }^{2}$ \\ ${ }^{1}$ Kryvyi Rih Professional Mining and Metallurgical Lyceum \\ ${ }^{2}$ I. Horbachevsky Ternopil State Medical University
}

\begin{abstract}
The article substantiates the expediency of studying of medical and social aspects of cardiovascular health among different groups of population, assessing the cardiovascular risk and lifestyle modifications, as well as the skills of the nurse's preventive work in this aspect.
\end{abstract}

Вступ. Проблема серцево-судинної захворюваності та смертності на сьогодні в Україні постає особливо гостро. Внаслідок хвороб системи кровообігу Україна втрачає щорічно майже 500 тис. населення. Рівень загальної захворюваності на серцево-судинні захворювання (ССЗ) постійно зростає. За даними вітчизняної та зарубіжної наукової літератури, одним із визначальних чинників складної демографічної ситуації в Україні $є$ зростання медико-демографічних втрат населення внаслідок передчасної смертності, у структурі якої чільне місце посідають саме хвороби системи кровообігу - 67,29 \% [1].

В Україні захворюваність і смертність внаслідок серцево-судинних хвороб у 1,5-2 рази вищі, ніж у розвинених економічних країнах. Останнім часом серцево-судинна захворюваність значно помолодшала. Виникає необхідність у проведенні первинної профілактики ССЗ, тобто заходів щодо запобігання виникненню хвороб серця у здорових людей. Ці заходи є ефективними при їх застосуванні в осіб, які

(ㄱ І. В. Радіонова, Л. В. Левицька, 2018 вже мають серцево-судинні хвороби, оскільки вони не просто гальмують розвиток захворювання, а й підвищують якість життя та подовжують тривалість життя пацієнтів.

Профілактика ССЗ - це скоординовані на суспільному та індивідуальному рівнях дії, що спрямовані на усунення або зменшення впливу ССЗ і пов'язаної з ними інвалідності. Тому профілактика ССЗ, яка залишається важливим завданням для системи охорони здоров'я та популяції в цілому, повинна посідати провідне місце в національних програмах збереження чисельності працездатного населення [2].

Розвиток серцево-судинних хвороб тісно пов'язаний зі способом життя, зокрема з курінням, нездоровим харчуванням, недостатньою фізичною активністю, а також психосоціальними чинниками. За даними Всесвітньої організації охорони здоров'я, більш, ніж три чверті усіх випадків смерті від ССЗ можна уникнути за допомогою модифікації способу життя. Тому розуміння причин виникнення і прогресування серцево-судинних захворювань та активний вплив 
на них $\epsilon$ на сьогодні одним із найдієвіших способів не тільки зменшити серцево-судинну смертність в Україні, але й запобігти розвитку багатьох інших захворювань, покращити тривалість та якість життя пацієнтів.

Основна частина. Відповідно до сучасних рекомендацій, профілактика ССЗ ґрунтується на концепції чинників ризику розвитку серцево-судинних захворювань, основою якої є модифікація способу життя з метою запобігання виникненню захворювань ще на доклінічних стадіях їх розвитку [3]. Фактори ризику ССЗ виявляють та оцінюють за даними анкетування пацієнтів, вимірювання артеріального тиску, антропометрії, визначення у крові рівнів загального холестерину (ліпідних фракцій) та глюкози.

Досвід розвинених країн світу (Японія, США, Канада) з впровадженням широкомасштабних кардіологічних програм, спрямованих на модифікацію факторів ризику ССЗ, свідчить, що провідною серед них є модифікація способу життя та корекція факторів ризику.

Основними факторами ризику виникнення СС3, за даними Фремінгемського дослідження, $\epsilon$ :

- стать та вік;

- артеріальна гіпертензія;

- підвищений холестерин;

- цукровий діабет;

- тютюнокуріння.

Упродовж XX-XXI ст. невпинно продовжуються пошуки факторів ризику ССЗ. Дослідження INTERHEART $\epsilon$ ще одним важливим етапом, під час якого було виділено такі фактори ризику:

- артеріальна гіпертензія;

- абдомінальне ожиріння;

- підвищення глюкози в крові;

- підвищені показники ліпідного профілю;

- недостатня фізична активність;

- тютюнокуріння;

- недостатнє споживання фруктів та овочів.

Умовно їх було поділено на модифіковані, - тобто ті, на які варто впливати, здійснюючи профілактичні заходи (тютюнокуріння, надмірне вживання алкоголю, нераціональне харчування, гіподинамія, надлишкова маса, підвищений артеріальний тиск, порушення ліпідного та вуглеводного обмінів), та немодифіковані, - впливати на які неможливо (вік, стать, спадковість).

Найпоширенішим фактором ризику, за даними В003, у світі серед країн із середнім рівнем доходів $\epsilon$ артеріальна гіпертензія. Найбільший самостійний внесок у популяційний рівень серцево-судинного ризику має підвищений артеріальний систолічний тиск, що є одним із основних факторів ризику та незалежним предиктором серцево-судинних подій (ССП). Поширеність артеріальної гіпертензії станом на 2014 р. в Україні серед чоловіків становила 33,4 \%, серед жінок - 25,2 \%, і відповідає одним із найвищих показників у Європі.

За даними Фремінгемського дослідження, тютюнокуріння вдвічі підвищує ризик розвитку стенокардії та інфаркту міокарда і майже в 5 разів - виникнення раптової смерті. Тютюнокуріння - незалежний фактор ризику, але його негативна дія підвищується у 5-8 разів при поєднанні з іншими факторами ризику - артеріальною гіпертензією, дисліпідемією, ожирінням та гіподинамією. Усі форми вживання тютюну, включно куріння сигарет, сигар, трубок, жувального або нюхального тютюну, а також вплив продуктів його згорання на тих, хто не курить, значно підвищують захворюваність і передчасну смертність. Відомо, що пасивне тютюнокуріння підвищує ризик розвитку ССП на 30 \%, становить одну з найважливіших медикосоціальних проблем. Тому дуже важливо розвивати державні стратегії припинення тютюнокуріння та підбирати для кожного курця індивідуальні чи групові програми [3].

Фізична культура $є$ основним методом первинної та вторинної профілактики. Наявні дані чітко вказують на те, що фізична активність знижує серцевосудинний ризик не лише серед осіб із нормальним індексом маси тіла, а й тим, хто має надлишкову масу або ожиріння. Недавній аналіз даних декількох досліджень показав, що особи з нормальною масою, які мали достатню фізичну активність, жили на 4,7 року довше, ніж особи, які не мали вільного часу для фізичної культури. Останнім часом розвинувся інтерес до розуміння впливу «сидячого способу життя» на здоров'я, незалежно від рівня фізичної активності. Людина може бути фізично активною, але з сидячим способом життя (наприклад працівник офісної служби, який сидить протягом більшої частини робочого дня, але регулярно займається спортом). Дослідження продемонстрували, що сидяча поведінка пов'язана з підвищеним рівнем кардіометаболічних біомаркерів та $є$ ще одним важливим серцево-судинним фактором ризику [4].

Надлишкова маса тіла та ожиріння мають прямий кореляційний зв'язок з ризиком виникнення ССП та 
$\epsilon$ незалежними предикторами виникнення ХСК. Дані численних спостережень та рандомізованих клінічних випробувань підтвердили суттєві переваги для здоров'я від втрати маси при надлишковій масі тіла. Втрата маси 5-10 \% пов'язана з суттєвим зниженням артеріального тиску серед людей з гіпертензією або без неї. Втрата маси покращує профіль ліпопротеїдів, забезпечуючи зниження рівня тригліцеридів у сироватці крові, підвищення рівня холестерину лпвщ та незначне зниження загального холестерину та холестерину лПнщ, а також поліпшення толерантності до глюкози та резистентності до інсуліну [5].

Профілактика ССЗ є одним із найпріоритетніших завдань, оскільки 2/3 факторів ризику зумовлені способом життя, серед яких до психосоціальних відносять різноманітні стресогенні події життя, хронічний стрес на роботі, відсутність соціальної підтримки, низький соціально-економічний статус, напруженість сімейних стосунків та ін. 3 іншого боку, епідеміологічні дані свідчать про зростання поширеності ССЗ, незважаючи на зусилля медичної спільноти. Невідповідність між реалізованими зусиллями та отриманими результатами змушує думати про багатовимірний вплив факторів ризику, середовищем для прояву яких $є$ психосоціальна сфера людини. Впровадження профілактичних програм із усунення дії основних модифікованих факторів ризику свідчить про можливість зниження розповсюдженості та смертності від СС3 на 30-40 \% [6].

3 огляду на високу ефективність впливу модифікації стилю життя на зниження серцево-судинних ризиків було проведено анкетування 210 учнів та працівників Криворізького професійного гірничометалургійного ліцею, а також членів їхніх родин, за допомогою «Експрес-опитувальника», який включав оцінку основних факторів ризику серцево-судинних подій. Серед опитаних було 97 (46,19 \%) жінок та 113 (53,81\%) чоловіків, середній вік яких становив $(54,30 \pm 17,44)$ року $(22-80$ років). Підвищений артеріальний тиск було виявлено у 36 (37,11\%) чоловіків і 32 (28,32 \%) жінок, відповідний показник по Україні становить 36,3 \%. Достовірно вищим був показник поширеності тютюнокуріння серед чоловіків 29,90 \% (29 осіб), ніж серед жінок - 21,24 \% (24 особи), в середньому значення по Україні - 18,4 \%. Проаналізувавши ступінь фізичної активності серед опитаних, визначили, що недостатню фізичну активність мали 65 (67,01\%) жінок і 73 (75,26 \%) чоловіків. Поширеність надлишкової маси тіла та ожиріння в середньому по Україні становить 60,5 \%, а серед обстежених чоловіків та жінок цей показник склав, відповідно, 52,58 і $61,06 \%$. Виявилось, що 67,01\% опитаних осіб чоловічої статі та 65,49 \% жіночої зловживають жирною та смаженою їжею. Більше 80,0 \% опитаних обох статей перебувають в умовах хронічного побутового або соціального стресу.

Проведене анкетування дозволило визначити рівні кардіоваскулярного здоров'я (КВЗ) за шкалою «Life's Simple 7». Серед жінок високий рівень КВ3 мали 16 (14,16 \%) обстежених, середній - 76 (67,26 \%) та низький - 21 (18,58 \%) осіб; серед чоловіків - з високим рівнем кардіоваскулярного здоров'я було виявлено 12 осіб (12,37 \%), середнім - 67 (69,07 \%) та низьким 18 анкетованих (18,56 \%).

Висновки. 1. Існуюча доказова база свідчить про те, що дотримання засад здорового способу життя та корекція факторів ризику мають позитивний вплив на попередження розвитку серцево-судинних захворювань та їх ускладнень.

2. Поширеність основних факторів ризику серцевосудинних подій серед учнів і працівників спеціалізованого закладу середньої технічної освіти $є$ високою та достовірно не відрізняється по усіх основних факторах порівняно із середньостатистичними показниками по Україні.

3. Переважна більшість обстежених серед учнів і працівників спеціалізованого закладу середньої технічної освіти мають середній та низький рівні кардіоваскулярного здоров'я.

4. Значна поширеність факторів ризику серцевосудинних подій та низький рівень кардіоваскулярного здоров'я серед учнів і працівників спеціалізованого закладу середньої технічної освіти підтверджує важливість інформування населення та проведення заходів з модифікації факторів ризику.

5. Обґрунтованим є оцінка факторів ризику серцево-судинних подій серед учнів і працівників спеціалізованого закладу середньої технічної освіти та надання інформації медичними сестрами цих закладів стосовно профілактики факторів ризику серцевосудинних захворювань.

Перспективною $є$ розробка програм із визначення факторів ризику серцево-судинних подій серед учнів та працівників спеціалізованих закладів середньої технічної освіти та їх модифікації. 


\section{СПИСОК ЛІТЕРАТУРИ}

1. Щорічна доповідь про стан здоров'я населення, санітарно-епідемічну ситуацію та результати діяльності системи охорони здоров'я України. 2017 рік / МОЗ, ДУ УІСД МОЗ України. - К., 2018. - 516 с.

2. Estimation of ten-year risk of fatal cardiovascular disease in Europe: the SCORE project / R. M. Conroy, K. Pyorala, A. P. Fitzgerald [et al.] // Eur. H. J. - 2003. - Vol. 24. - P. 987-1003.

3. 2016 European guidelines on cardiovascular disease prevention in clinical practice. The sixth joint task force of the European Society of Cardiology and other societies on cardiovascular disease prevention in clinical practice (constituted by representatives of 10 societies and by invited experts). Developed with the special contribution of the European association for cardiovascular prevention \& rehabilitation (EACPR) / M. F. Piepoli, A. W. Hoes, S. Agewal [et al.] // Eur. J. Prev. Cardiol. - 2016. - Vol. 23. - P. NP1-NP96.

4. Effect of potentially modifiable risk factors associated with myocardial infarction in 52 countries (the INTERHEART study): case-control study / S. Yusuf, S. Hawken, S. Ounpuu [et al.] // Lancet. - 2004. - Vol. 364. - P. 937-952.

5. http://moz.gov.ua/article/news/moz-ukraini-predstavilorekomendacii-zi-zdorovogo-harchuvannja

6. http://moz.gov.ua/article/health/porivnjajte-svoju-izhuz-«tarilkoju-zdorovogo-harchuvannja»

Отримано 05.12.18 